\title{
Elements that affect foreign tourists' satisfaction: a case study in Seoul, Korea
}

\author{
Chehyun Ryu ${ }^{1}$ - Youngsang Kwon ${ }^{2,3}$
}

Accepted: 1 March 2021 / Published online: 29 March 2021

(c) The Author(s) 2021

\begin{abstract}
City tourism is one of the fastest growing industries worldwide. City tourism based on the attractiveness of the city is an important policy objective to secure competitiveness and sustainability of the city. However, as a city attracts more tourists, this uniqueness tends to decrease with the introduction of global corporate franchises as well as the construction of standardised buildings. Policymakers focus more on building hotels and shopping centres than on enhancing the cityscape. Therefore, this article aims to analyse the effect of cityscapes on tourist satisfaction. It encourages policymakers to bear in mind what really matters in fostering tourist satisfaction. During this research, about 250 foreign tourists visiting Seoul were given questionnaires to complete. Ordered logistic regression was used to analyse the data collected. The results demonstrated that among several elements that affected tourist satisfaction, such as shopping, security, and public transportation services, the cityscape had the greatest influence. This fact shows that urban competitiveness and sustainable city tourism are more important than the construction of new buildings or infrastructure in the short term. In the future, policymakers should seek to strengthen the city's competitiveness from a longer-term perspective for its sustainable economic revitalisation.
\end{abstract}

Keywords Cityscape $\cdot$ City tourism $\cdot$ Satisfaction $\cdot$ Physical environment $\cdot$ Seoul

\section{Introduction}

Developments in transportation have enabled easy and fast movement of people internationally, allowing them to visit foreign countries. The number of people embarking on international travel increases annually, resulting in the expansion of the tourism industry (Ashworth and Tunbridge 1990; Edwards et al. 2008; Law 1993). The advent of the Internet has especially transformed global tourism by allowing easy access to information about tourist destinations. While in the past, international travellers were mainly elderly tourists, the number of younger people aged between 20 and 50 travelling

Youngsang Kwon

yskwon@snu.ac.kr

1 Yongin Research Institute 5F, 15-17, Myeongji-ro 40beon-gil, Cheoin-gu, Yongin-si 17056, Korea

2 Department of Civil and Environmental Engineering, Seoul National University, 1 Gwanak-ro, Gwanak-gu, Seoul 08826, Korea

3 Advanced Institute of Convergence Technology, 145 Gwanggyo-ro, Yeongtong-gu, Suwon-si 16229, Gyeonggi-do, Korea alone is now increasing (Ahn 2011; Fernández-Herrero et al. 2018). This has led to a change in the purpose of travelling for many people, who now have multiple reasons to travel, from visiting tourist destinations including museums and heritage sites to experiencing and embracing local culture. Among the various factors that influence tourist satisfaction, these shifts highlight the importance of the physical environment of the destination, as well as the attractiveness of the destination itself, the costs incurred in travelling, and the climate (Liu 2015; Wang and Hsu 2010; Parahoo et al. 2014; Agyeiwaah et al. 2019). Notable factors that attract tourists to world major cities include the unique architecture, historic sites and buildings, parks, shopping districts, and cultural impressions combined in streets and buildings.

While analysis of the influence of the destination's physical environment on tourism is steadily increasing, little research has been conducted in this area. Among similar studies on urban residents, some have examined satisfaction with scenery and the impact of the physical environment on location or city image (Ashworth and Tunbridge 1990; Eizenberg and Cohen 2015), but these have not included foreign tourists. Despite neglecting urban tourism in preference for urban residents, researchers have been discussing the rise 
in urban tourism research since the 1990s (Haywood and Muller 1988; Wearing and Foley 2017; Selby 2004; Edwards et al. 2008). Compared to residents, tourists experience the physical space of a city based on various factors, including the purpose of their visit, their nationality, and the duration of their stay, so these elements should be taken into consideration.

Until the 1980s, city tourism had not been a subject of scholarly attention due to its complexity (Edwards et al. 2008). Since tourism in a large city is connected to many other aspects of the city, it is almost impossible to distinguish between the multiple effects of tourism on promoting city prosperity, economic growth, and tourist amenities. However, since the 1980s, as the tourism industry began to bring economic benefits to cities by solving long-term problems of economic depression and unemployment, it could no longer be overlooked (Karski 1990). Since then, city tourism has become an important field of academic research. Various studies were published on city tourism from the 1990s onward, although numerous factors that affected city tourism remained largely undiscovered. This research focused on the fact that the foreign tourists favour exotic architecture and civic scenery, historic buildings and heritage sites, parks and open places, shopping districts, and cultural impressions combined in streets and buildings. This research proves how important the physical environment is to foreign tourists.

The number of foreign tourists visiting Korea has increased rapidly over the last decade (Fig. 1) and more than $80 \%$ of the foreign tourists who visit Korea, visit Seoul (International Visitor Survey 2018 by Ministry of Culture, Sports and Tourism, http://data.seoul.go.kr). For the convenience of visitors, the city government has focused on building more hotels and shopping centres in the central business district (CBD) area of Seoul, which has been the nation's capital since 1394. Newly built structures are taking over what is left of the capital's history. Thus, the purpose of this study is to analyse the importance of cityscapes and lively streets for tourist satisfaction to emphasise the importance of preserving the city's appearance.

In this study, other factors that influence city tourism besides the physical environment, such as shopping, public transportation service, travel expenditure, etc. were measured and controlled. As elements of the physical environment, such as architecture, roads, streetscapes, open spaces, and landmarks, are generally the basic factors that form a region's identity and image, they significantly influence the competitiveness of a destination for foreign tourists. In this article, 'urban factor' refers to the aspects of the physical environment that affect tourists. The 'urban factor' is measured in terms of 'cityscape' and lively streets because many people tend to see the cityscape two-dimensionally, that is, like a picture. Although viewer satisfaction with magnificent urban scenery, like that seen on postcards, may be high, a popularly visited city might not be as appealing if it is too quiet. In short, the physical environment that one recognises while visiting a city is different from the built scenic environment of that city and includes streetscapes and lively streets in addition to simple visual images.

To measure the effect of urban factors on tourist satisfaction, surveys were carried out and the results were analysed through ordered logistic regression. Satisfaction was measured as the difference between expectation and actual
Fig. 1 Number of foreign tourists visiting Korea (http://data. seoul.go.kr)

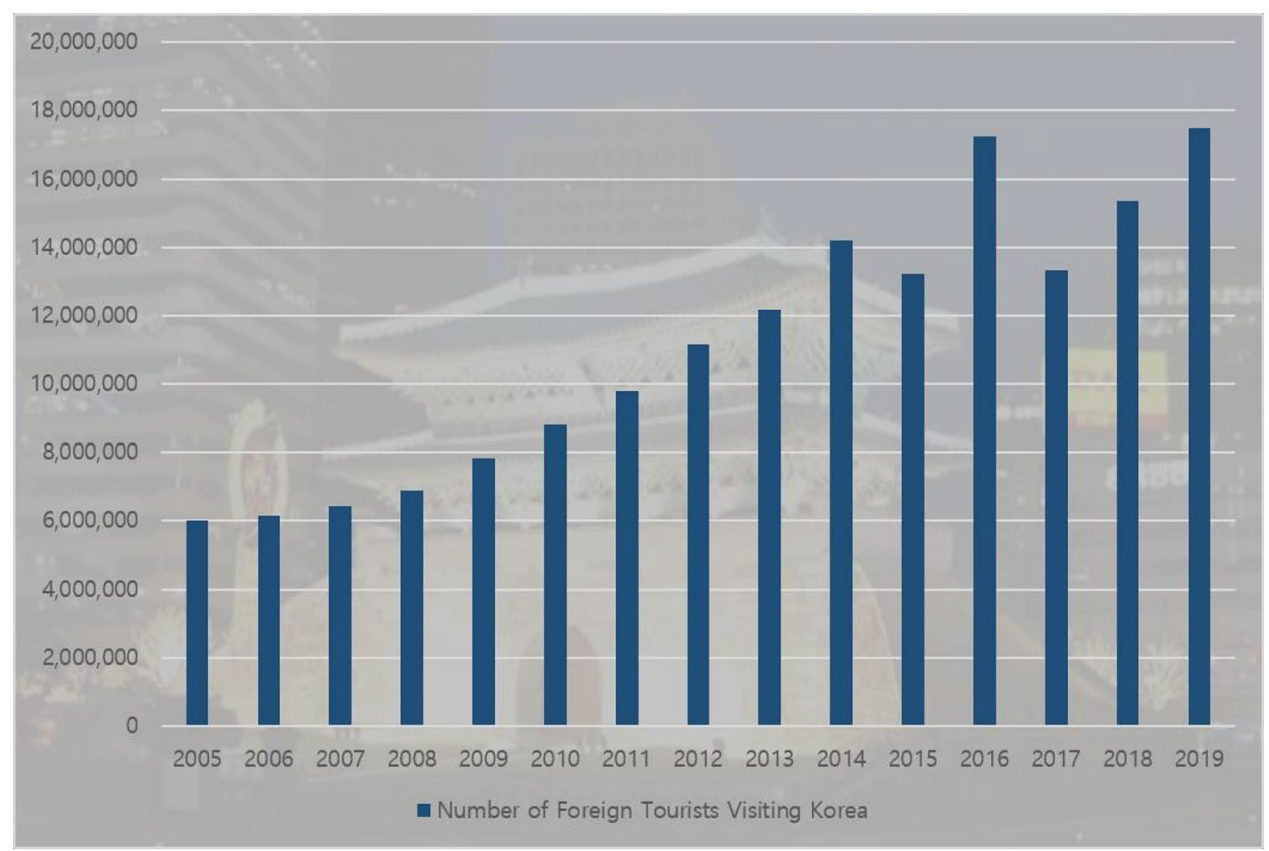


experience. Tourism factors were chosen from past theoretical studies and by referencing past and current national surveys.

The rest of this paper is structured as follows. "Theoretical background" section offers an insight into the theoretical background of urban tourism and analyses the relationship between urban competitiveness and city tourism through a review of the relevant literature. "Materials and methods" section presents the materials and methods used in this study. It specifically outlines the general methodology as well as the survey and the statistical model used in this study. "Results and discussion" section presents the results after using ordered logistic regression to analyse the data gathered. "Conclusion" section discusses the key findings and explains the implications of this study.

\section{Theoretical background}

Urban tourism has, in one form or other, been with us since Mesopotamia and Sumeria were spawning the phenomenon of urbanization. People with the means and inclination to do so have been drawn to towns and cities just to visit and experience a multiplicity of things to see and do... These towns and cities were the melting pots of national culture, art, music, literature and magnificent architecture and urban design. It was the concentration, variety, and quality of these activities and attributes... that created their attraction and put certain towns and cities on the tourism map... (Karski 1990, p. 15)

Although large cities have been the centre of tourism since the origin of cities, city tourism had not been accepted as an academic field until the 1980s (Hinch 1996; Stansfield 1964; Christaller 1963). Among large cities, the capital city of a country best represents its identity. It is where the most current trends of the country can be experienced.

Until the 1900s, cities were considered the origin of tourist inflow, while non-urban places were considered tourist destinations (Stansfield 1964). Until the mid-1980s, most scholars agreed with Christaller's (1963) opinion that the purpose of tourism was to travel from urban to non-urban areas for recreation and entertainment (Ashworth and Tunbridge 1990). Thus, tourist cities were limited to resort cities (mostly cities by beaches or lakes), such as Aspen in Colorado and Acapulco in Mexico, until the 1980s. The role of tourism was ignored even in the largest tourist cities of today, such as Paris or Rome (Edwards et al. 2008; Page 1993; Crompton 1979). The reason tourism was overlooked for such a long time was due to its complexity, since tourism in a large city is connected to many other aspects of the city. For instance, the purpose of a visit may not be tourism alone, but also visiting friends or relatives, or for business. In such cases, tourism is added on. Consequently, it is difficult to separate tourism from countless other elements of a city.

Tourist sites are shared spaces, in that most tourist attractions are cultural and recreational facilities for citizens and enhance city life for them. In other words, tourism is just one of many economic activities within a city that competes with several other industries for resources such as labour and land (Law 1993). Planning and managing tourist activities is made more complex by the necessary engagement between tourism and the multiplicity of public and commercial organisations with varying levels of involvement with tourism in urban areas (Iso-Ahola 1982).

As a result, tourism had not received scholarly attention until the 1980s (Mannell and Iso-Ahola 1987; Gospodini 2001). However, because of the decline of long-established industries, deteriorating town centres, and high levels of unemployment since the 1980s, planners and urban governments began to treat tourism as a significant component of a diversified strategy to counteract these trends (Turner 1973; Cohen 1979; Barker 2002). The tourism industry has brought about economic benefits to several cities. It has been used in urban revitalisation programs in places such as Baltimore and Liverpool. Many jobs were created in the process, solving the unemployment problem, and many recent city centre redevelopment initiatives were driven partly by the expectation of increased revenues from tourism (Cohen 1979; Owen 1990).

As the revenues from city tourism became too significant to be ignored, it became an independent industry and an important field of academic research in the 1990s. Since then, various studies on city tourism have emerged and it continues to remain a growing academic field. Early studies were led by countries where the city tourism industry was well developed such as the US and Europe. Among the early studies were those conducted by Burgess (1982), Pearce (1977), Judd and Collins (1979), and Bradley et al. (2002) which were based on Lynch's (1960) ideas on city imaging.

The rapid increase in the number of tourists is welcome in many cities, given that it creates jobs and increases profits. However, although tourism brings economic vitality to a city, it also creates numerous problems such as the overburdening of city infrastructure, the destruction of historical sites, conflict with local residents, and pollution. This is especially true in fast-changing cities like Seoul, where an increase in the number of tourists can change the physical form of the city in just a few years. However, since the income gained from tourism is a major source of revenue for many cities, it is difficult to make any political or economic decisions that may lead to a decrease in the number of tourists.

The number of foreign tourists visiting Korea has been increasing over the last decade. In 2012, more than 10 
million foreign tourists came to Korea. To accommodate the increasing number of tourists, the government issued a special law regarding hotels for tourists in July 2012. The purpose of the law was to supply accommodation to tourists visiting Seoul. Between 2012 and 2015, 150 hotels (17,816 rooms) were built in Seoul (Seoul Metropolitan Government, http://english.seoul.go.kr/). The government allowed taller hotels and higher floor area ratios, relaxed regulations on parking spaces, and offered various other forms of preferential treatment. The number of hotels built each year continues to be high, and these hotels have replaced the old fabric of Seoul. As a result, there have been problems regarding alterations to the scenery and the hotels being located very close to schools. Due to relaxed building height regulations for hotels, these buildings stood out in many places, blocking out the familiar cityscape.

The increasing number of hotels replacing the fabric of the old city is only a small example of the changes that have taken place in Seoul. As the number of tourists increased over the last few years, smaller shops were replaced with global franchises and duty-free shops in the downtown Seoul area. Although some changes are inevitable, radical change carries the risk of governments losing the support of local residents. Sufficient accommodation and modern shopping malls may increase convenience for tourists, but it is important to remember that the main purpose of tourism is to experience a new environment and enjoy the culture and exotic scenery of a new place.

Many studies on tourism support the fact that the motivation for tourism is to experience a new environment by distancing oneself from familiar situations (Kyle et al. 2004; Prayag and Ryan 2011; Brown and Raymond 2007). Through tourism, people expect to seek 'new worlds' by escaping their everyday lives (Wang et al. 2016). Scholars introduced a concept of 'anti-structure' and 'counterstructures' to define 'new worlds' (Della Corte and Micera 2011; Oliver et al. 1997). Scholars explain 'anti-structure' as a new environment that is different from the daily routine (Della Corte and Micera 2011; Oliver et al. 1997) and define 'counter-structures' as a new reality that is affected by the unique perceptions or circumstances of each individual (Chen et al. 2015).

With the proliferation of Internet use and advancements in technology, the purpose of tourism has shifted from functional to formal. Until the 1970s, the purpose of tourism was to get away from work and rest, and thus, tourist destinations were mainly recreational cities such as beaches and resorts. However, since the 1980s, tourism has become less of a functional phenomenon and more of a formal one (Wang et al. 2016). The Internet has allowed many activities, including work, to be conducted using a single tablet or laptop, thus loosening the ties between physical form and function involved in our daily undertakings. For instance, we no longer have to be physically in the office to write a report or give business orders, and activities such as banking, shopping, or education can be conducted with few physical space constraints. Thus, the physical space itself has become an important factor. For example, grocery shopping in the virtual space can take place in a café, park, or even overseas. Consequently, greater emphasis has been placed on the surrounding context and environment in tourism, turning large cities into major tourist destinations. In city tourism, tourists can carry out their everyday activities in completely different surroundings (Wang et al. 2016).

When tourists visit a destination, they develop a strong attachment to the surrounding environment (Wang 2016; $\mathrm{Yu}$ and Goulden 2006). Tourists tend to experience both cognitive and emotional bonds with the destination through positive interactions with it (Wang and Davidson 2010). Thereby, the physical environment of the place becomes the object of place attachment (Wang 2016), which is a critical factor in tourism and influences the tourists' tendency to revisit. Therefore, in this study, questionnaires were analysed to investigate how important the physical environments were to the tourists.

\section{Materials and methods}

\section{Surveys}

To analyse the impact of the cityscape on tourist satisfaction, surveys were conducted between September 2016 and October 2016 at a residence, a youth hostel, and a guesthouse, all of which were located in the Seoul CBD area (Fig. 2). The $\mathrm{CBD}$ area is the most symbolic area in Seoul where historical structures that date back to the fourteenth century coexist with modern architecture. It is also the area where most

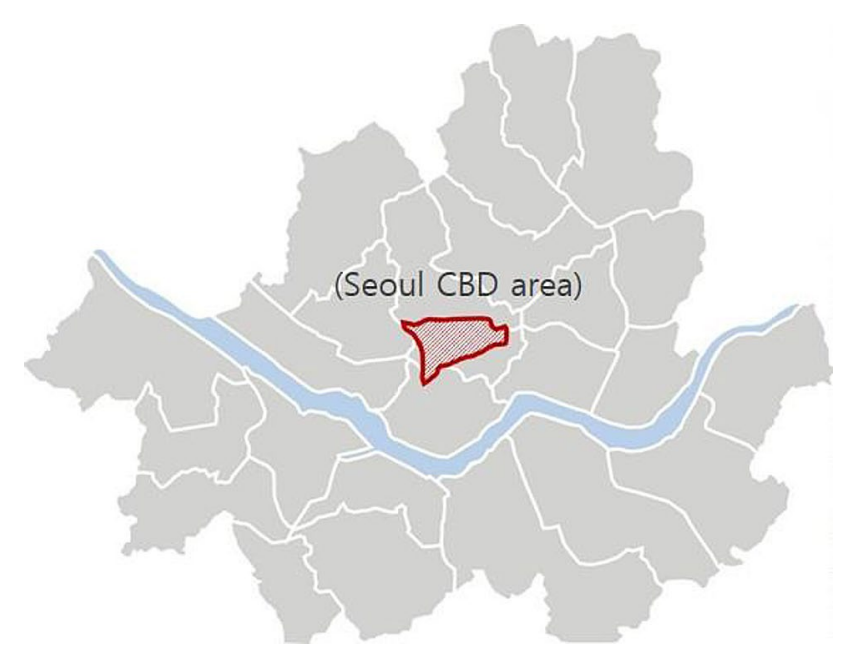

Fig. 2 Survey area (the old downtown of Seoul) 

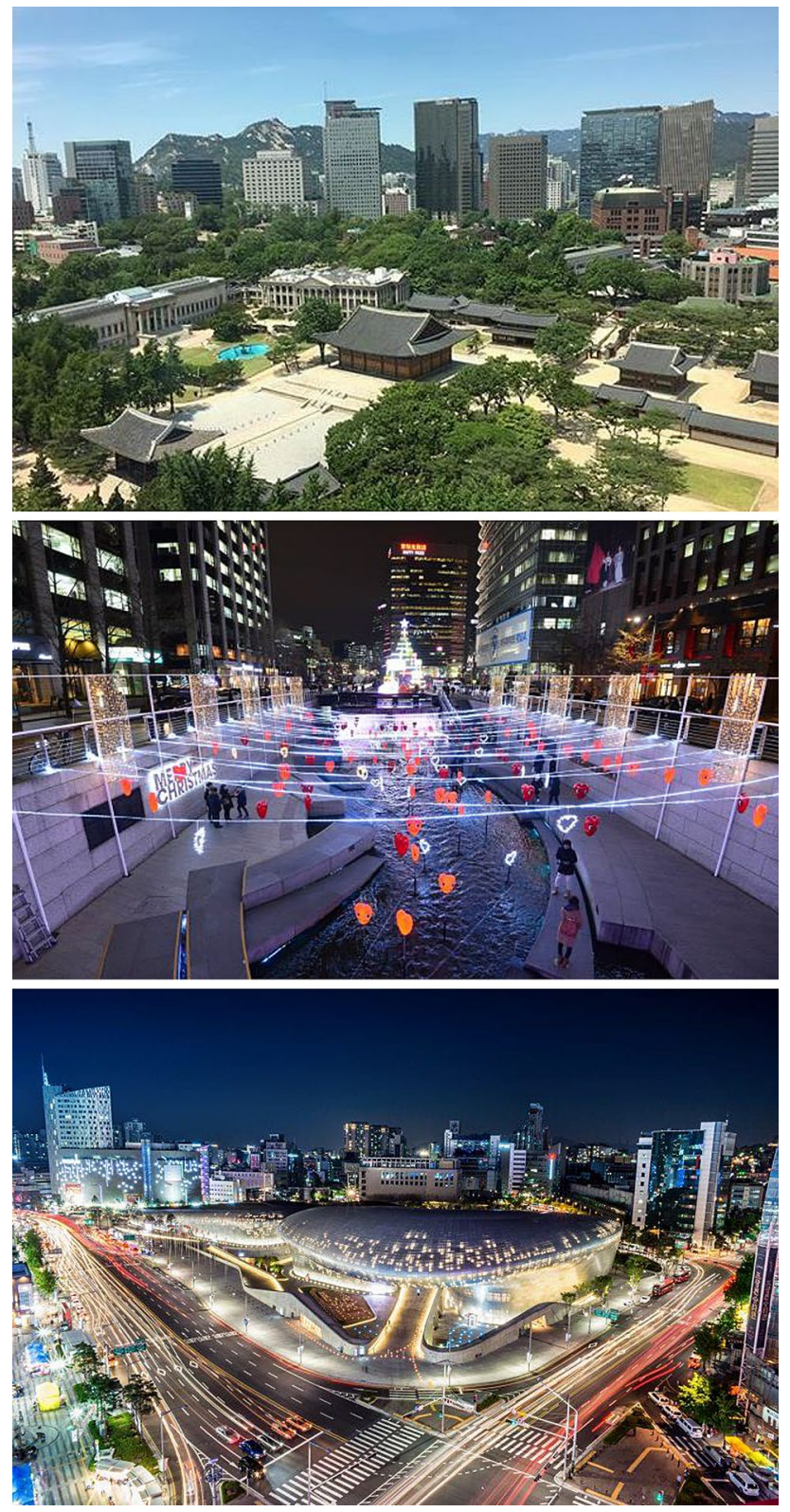

Fig. 3 Tourist sites in the CBD area in downtown Seoul: old palace of Joseon dynasty (Source: City of Seoul, top), Cheonggyecheon stream revitalization project (Source: Korea Tourism Organisation, middle), Dongdaemun Design Plaza (Designed by Zaha Hadid, Source: Korea Tourism Organisation, bottom)

tourist sites are located (Fig. 3). The subjects of the survey were foreign tourists who were visiting Seoul from North America and Europe. The age of the surveyed group ranged from 19 to 70 years. The questionnaires were distributed at night and collected in the morning.

A total of 220 surveys were collected from a distribution of 250 . Out of the 220 collected surveys, 202 were completed and included in the study. The ones that were excluded either had unreliable answers or too many blanks.
The questionnaires were distributed only to tourists who had stayed in Seoul for at least three days, to be sure that they had both time and opportunity to look around. To minimise the effect of the weather, the surveys were only distributed on the evenings of cool and sunny autumn days, which were appropriate for outdoor activity.

The survey focused on tourist elements and satisfaction, by asking questions on topics such as security, shopping, public transportation services, travel expenses, appeal of tourist sites, tourist information services, accommodation, food, unique architecture, beautiful cityscape, lively streets, overall satisfaction, the intention to revisit Seoul, and the intention to recommend Seoul as a tourist destination. What the tourists expected and experienced regarding each of these elements were measured using a 5-point Likert scale.

\section{Measuring satisfaction}

Satisfaction has always been a critical issue in business and marketing (Foster 1999; Johnson et al. 1995). Oliver (1980) defined satisfaction as the consumers' overall cognitive or affective response to product use, while Chen et al. (2015) defined satisfaction as the level of fulfilment that a product or service provides (Churchill and Surprenant 1982). The degree of complexity of an experience affects the psychological processes of satisfaction (Oliver 1980). City tourism, especially while travelling internationally, is a complex experience. Some aspects of travel may be satisfying while other aspects may not. The overall satisfaction of travel is accumulated satisfaction from numerous experiences in the process of travel (Chu and Choi 2000). How tourists perceive the quality of services and the prices they pay may affect the satisfaction they derive from each experience (Schewe et al. 1978; Tribe and Snaith 1998). Aside from the pivotal indicator of price, other intangible aspects of the service may also influence tourist satisfaction (Parasuraman et al. 1998; Crossley and Xu 1996).

There are various methods and metrics to measure consumer satisfaction. The importance-performance analysis (IPA) measures satisfaction based on two attributes, namely performance and importance (Fick and Ritchie 1991; Saleh and Ryan 1992). IPA is a simple but effective tool that is used to analyse satisfaction in marketing and other sectors including tourism. IPA recognises that tourists tend to consider some attributes of tourism to be more important than other attributes (Parasuraman et al. 1994). This method was used by Schewe et al. (1978) in a paper on the selection of a tourism destination in New England, US. Since the method of measuring the importance is by ranking, it is inadequate for measuring actual tourist satisfaction. For example, the security of a city may be a very important 
factor in selecting a destination, but it may not necessarily affect tourist satisfaction.

Another example is the service-quality model (SERVQUAL) which is commonly used. It was developed by Parasuraman et al. (1988) and Cronin and Taylor (1994) to measure the quality of service in marketing. There are 22 categories in SERVQUAL to assess the quality of service that the customers should have received and the quality of service that the customers actually received. It is measured on a 7-point Likert scale and the difference is used to evaluate the quality of the service (Alegre and Garau 2010). In tourism, SERVQUAL is commonly used to measure the service quality of hotels (Alegre and Garau 2010), flights (Ryan and Huyton 2002), and travel agencies (Oh 2001).

Although the SERVQUAL model is commonly used to measure customer satisfaction (McKelvey and Zavoina 1975), the expected service and ideal value are needed for a more comprehensive model. In other words, what a service provides is actually what an excellent service should provide in the SERVQUAL model (Hinch 1996). Thus, it is inadequate to evaluate expectations in tourism, as expectation has a relative value. Cronin and Taylor (1994) argued that measuring the service provided alone is more efficient than measuring the difference between what a service is expected to provide and what it actually provides. A PerformanceBased Measure of Service Quality (SERVPERF) model was presented based in their argument, but measuring only the outcome ignores the expense and the characteristics of the destination, so even this model was considered insufficient in measuring tourist satisfaction. Based on the pros and cons of IPA, and the SERVQUAL and SERVPERF models, Tribe and Snaith developed a Holiday-Satisfaction (HOLSAT) model to use in tourism research. In the HOLSAT model, satisfaction is assessed by measuring the difference between expectation and performance.

In most tourism-related surveys, the 5-point Likert scale is used to measure the satisfaction of tourists. National surveys, such as the International Visitor Survey, use the 5-point Likert scale (from 1 point $=$ very unsatisfied to 5 points $=$ very satisfied) to measure satisfaction with accommodation, food, security, etc. This kind of measurement tends to be biased towards higher points (Alegre and Garau 2010; Ryan and Huyton 2002). According to these studies, the elements that are highly considered in choosing a tourist destination tend to have higher points in terms of satisfaction. Since satisfaction is related to a tourist's subjective feelings or travel motivation, the simple measurement of satisfaction can be positively biased, making it less accurate (Alegre and Garau 2010; Ryan and Huyton 2002).

In this study, the difference between expectation and actual experience is used to measure satisfaction based on the HOLSAT model. The HOLSAT model is a combination of 'how to measure' and 'what to measure'. Since the measurement categories in the HOLSAT model are inadequate, only the method of measurement is applied. The expectations of each element before arriving in Seoul were measured along with what the tourist actually experienced. In a study by Tribe and Snaith (1998), where the HOLSAT model was first introduced, the results were only compared to identify the higher value. For example, if the value of expectation for food was higher than the value for the performance of food, then the tourist was considered to be dissatisfied with the food. However, in this study, the differences are used as variables to analyse the effect of each tourist element on overall average tourist satisfaction.

\section{Selecting variables}

The dependent variable in this study is average tourist satisfaction (Table 1). There are many ways to measure a tourist's satisfaction level, such as the intention to revisit, the intention to recommend the destination to others, and the overall satisfaction level. Each variable has a slightly different meaning. While answering the questionnaire on the intention to revisit, the respondents not only considered their satisfaction with travel, but also the time and budgetary constraints that could affect their ability to revisit the city. Therefore, the average value of overall satisfaction, the intention to revisit, and the intention to recommend the destination were used as dependent variables.

\section{Ordered logistic regression}

The ordered logit model is a regression model for an ordinal response variable. The model is based on the cumulative probabilities of the response variable: in particular, the logit of each cumulative probability is assumed as a linear function of the covariates with regression coefficients constant across response categories. Surveys relating to satisfaction are mostly ordinal. In this study, the rate of satisfaction was measured from 1 to 5 , with 1 being 'very dissatisfied' and 5 being 'very satisfied'. While it is tempting to use the linear regression model to analyse the ordinal outcomes, ordinal regression needs to be used because assuming equal distances between categories has several problems.

Let $\mathrm{Yi}$ be an ordinal response variable with $\mathrm{C}$ categories for the $i$ th subject, along with a vector of covariate $x i$. The regression model establishes a relationship between the covariates and the set of probabilities of the categories pci $=\operatorname{Pr}(Y i=y c \mid x i), c=1, \ldots, C$. Usually, regression models for ordinal responses are not expressed in terms of the probabilities of the categories, but rather, refer to convenient oneto-one transformations such as the cumulative probabilities gci $=\operatorname{Pr}(Y i \leq y c \mid x i), c=1, \ldots, C$. Note that the last cumulative probability is necessarily equal to 1 , and thus, the model specifies only $C-1$ cumulative probabilities. 
Table 1 Selection of variables

\begin{tabular}{|c|c|c|}
\hline & Variables & Method of measurement \\
\hline Controlled variables & $\begin{array}{l}\text { Security } \\
\text { Shopping } \\
\text { Public transportation service } \\
\text { Travel expense } \\
\text { Appeal of tourist site } \\
\text { Tourist information service } \\
\text { Accommodation } \\
\text { Food } \\
\text { Unique architecture }\end{array}$ & $\begin{array}{l}\text { The expectation and experience of each attribute is measured using a } \\
\text { 5-point Likert scale } \\
\text { The difference between the measured expectation and the actual experi- } \\
\text { ence is used in the statistical model }\end{array}$ \\
\hline Dependent variables & $\begin{array}{l}\text { Beautiful cityscape } \\
\text { Lively streets }\end{array}$ & \\
\hline Independent variables & $\begin{array}{l}\text { Overall satisfaction } \\
\text { Intention to revisit } \\
\text { Intention to recommend the destination }\end{array}$ & $\begin{array}{l}\text { Each variable is measured in a 5-point Likert scale } \\
\text { The average of the three attributes is used as the independent variable in } \\
\text { the statistical model }\end{array}$ \\
\hline Tourism characteristics & $\begin{array}{l}\text { Previous visit } \\
\text { Travel companion } \\
\text { Travel type }\end{array}$ & $\begin{array}{l}\text { Yes/no } \\
\text { Alone/family or relatives/friends/co-workers } \\
\text { Independent travel/Full-package tour } \\
\text { /Air-tel tour (flight and hotel travel package) }\end{array}$ \\
\hline Demographic characteristic & Gender & Male/female \\
\hline
\end{tabular}

An ordered logit model for an ordinal response $Y i$ with $C$ categories is defined by a set of $C-1$ equations, where the cumulative probabilities gci $=\operatorname{Pr}(Y i \leq y c \mid x i)$ are related to a linear predictor $\beta_{\mathrm{x}_{\mathrm{i}}}^{\prime}=\beta_{0}+\beta_{1} \mathrm{x}_{\mathrm{I}},+\beta_{2 \mathrm{x}_{2 \mathrm{i}}}+\ldots$ through the logit function:

$\operatorname{logit}(\mathrm{gci})=\log (\mathrm{gci} /(1-\mathrm{gci}))=\alpha_{\mathrm{c}}-\beta_{\left(x_{i}\right)}^{\prime} \quad c=1,2, \ldots C-1$.

The parameters $\alpha_{\mathrm{c}}$, called thresholds or cut-points, are in increasing order $\left(\alpha_{1}<\alpha_{2}<\alpha \cdots<\alpha_{C-1}\right)$. It is not possible to estimate the overall intercept $\beta_{0}$ and all the $C-1$ thresholds simultaneously. In fact, adding an arbitrary constant to the overall intercept $\beta_{0}$ can be counteracted by adding the same constant to each threshold $\alpha_{\mathrm{c}}$. This identification problem is usually solved by either omitting the overall constant from the linear predictor (i.e. $\beta_{0}=0$ ) or fixing the first threshold at zero (i.e. $\alpha_{1}=0$ ).

The vector of the slopes $\beta$ is not indexed by the category index c. Thus, the effects of the covariates are constant across response categories. This feature is called a parallel regression assumption. Indeed, plotting logit (gci) against a covariate yields C-1 parallel lines (or parallel curves in the case of a non-linear specification, for example, a polynomial regression). In model (1) the minus before $\beta$ implies that increasing a covariate with a positive slope is associated with a shift towards the right-end of the response scale, namely a rise of the probabilities of the higher categories. Some authors write the model with a plus before $\beta$. In such cases, the interpretation of the effects of the covariates is reversed.

From Eq. (1), the cumulative probability for category $\mathrm{c}$ is

$$
\begin{aligned}
\operatorname{gci} & =\exp \left(\alpha_{\mathrm{c}}-\beta^{\prime} x_{i}\right) /\left(1+\exp \left(\left(\alpha_{\mathrm{c}}-\beta^{\prime} x_{i}\right)\right)\right. \\
& =1 /\left(1+\exp \left(-\left(\alpha_{\mathrm{c}}+\beta^{\prime} x_{i}\right)\right) .\right.
\end{aligned}
$$

Seven to eight different combinations were made from the average of the three attributes. There should be more numbers, but the combinations such as 1 (overall satisfaction), 1 (revisit intention), and 1 (intentions to recommend) did not appear. Since the data of average satisfaction is not continuous, multiple regressions cannot be used. Although the gap between each value cannot be defined as equivalent, the hierarchy exists. Thus, the ordered logistic model is most adequate for this analysis.

\section{Results and discussion}

\section{Satisfaction rate}

While tourists show high expectations for 'shopping', 'appeal of the tourist site', and 'food', they actually show high performance for 'shopping', 'security', and 'public transportation service' (Table 2).

The satisfaction of each factor of tourism is measured by the difference between the expectation and actual 
Table 2 Average of expectation, experience, and satisfaction

\begin{tabular}{llll}
\hline Variables & Expectation & Experience & $\begin{array}{l}\text { EExpe- } \\
\text { rience- } \\
\text { expecta- } \\
\text { tion }\end{array}$ \\
& & 4.43 & 0.35 \\
\hline Security & 4.09 & 4.31 & 0.24 \\
Shopping & 4.07 & 4.44 & 0.34 \\
Public transportation & 4.10 & & \\
$\quad$ service & 3.87 & 4.00 & 0.13 \\
Travel expense & 4.47 & 4.49 & 0.02 \\
Appeal of tourist site & 4.22 & 4.15 & -0.07 \\
Tourist information service & 4.23 & 4.32 & 0.09 \\
Accommodation & 4.37 & 4.52 & 0.15 \\
Food & 4.09 & 4.28 & 0.19 \\
Architecture & 3.78 & 4.11 & 0.34 \\
Cityscape & 4.14 & 4.40 & 0.26 \\
Lively streets & & 4.40 & \\
Overall satisfaction & & 4.18 & \\
Revisit intention & & 4.36 & \\
Recommendation intention & & &
\end{tabular}

experience. Thus, in the process of adding all the values to calculate the average, the added values will converge to zero. The elements that have high rates of satisfaction are 'security', 'architecture', and 'cityscape', while the elements that had low rates of satisfaction are 'tourist information service' and 'appeal of the tourist site' (Table 3).

\section{Tourist elements that affect tourist satisfaction}

The result of the ordered logistic regression is presented in Table 3. From the significance levels observed, both urban factors, namely 'beautiful cityscape' and 'lively streets', are all related to average tourist satisfaction. The positive coefficients mean that the more the tourists are satisfied with the cityscape or streets, the stronger the possibility of their having a higher level of average tourist satisfaction.

Besides the urban factors, other tourist factors except for 'security' and 'tourist information service' are positively related to average tourist satisfaction, which can be predicted. Although the coefficients in the ordered logistic regression cannot be directly read as regular OLS coefficients, the possibilities can be compared among the variables that share the same scale. Since the scale of urban factors and other factors of tourism are the same, the coefficients among these variables can be compared such that a higher coefficient value means a higher relativity to the dependent variable. For example, 'beautiful cityscape' is more sensitively related to average tourist satisfaction than are 'lively streets'. However, the degree of relativity cannot be compared, as 'beautiful cityscape' is $0.911 / 0.662$ times more sensitive for average tourist satisfaction. To find the
Table 3 Ordered logistic regression results

\begin{tabular}{|c|c|c|c|c|}
\hline & Variables & $\beta$ & Std. error & Sig \\
\hline \multirow[t]{2}{*}{ Urban factors } & Beautiful cityscape & 1.258 & .201 & .000 \\
\hline & Lively streets & 1.043 & .249 & .000 \\
\hline \multirow[t]{9}{*}{ Other tourism factors } & Unique architecture & .593 & .222 & .007 \\
\hline & Security & .229 & .179 & .201 \\
\hline & Shopping & .987 & .235 & .000 \\
\hline & Public transportation service & .756 & .228 & .001 \\
\hline & Travel expense & .535 & .245 & .029 \\
\hline & Appeal of tourist site & .898 & .280 & .001 \\
\hline & Tourist information service & .048 & .214 & .823 \\
\hline & Accommodation & 697 & .267 & .009 \\
\hline & Food & .582 & .281 & .039 \\
\hline \multirow[t]{10}{*}{ Tourist characteristics } & Previous visits $=$ no & -0.207 & .322 & .519 \\
\hline & Previous visits $=$ yes & $0 \mathrm{a}$ & & \\
\hline & Travel companion $=$ alone & .494 & .846 & .559 \\
\hline & Travel companion $=$ family & -0.241 & .547 & .659 \\
\hline & Travel companion $=$ friends & -0.336 & .523 & .521 \\
\hline & Travel companion $=$ co-workers & $0 \mathrm{a}$ & & \\
\hline & Travel type $=$ independent travel & .323 & .365 & .377 \\
\hline & Travel type $=$ air-tel tour & $0 \mathrm{a}$ & & \\
\hline & Gender $=$ male & .132 & .316 & .675 \\
\hline & Gender $=$ female & $0 \mathrm{a}$ & & \\
\hline Nagelkerke & & .880 & & \\
\hline
\end{tabular}


degree of relativity, each variable needs further calculation. However, since the purpose of this study was to discover the sequence of the variables, further calculation was considered unnecessary.

The observed significance levels in Table 3 show that 'beautiful cityscape' and 'lively streets' are all related to average tourist satisfaction. Other tourist factors, such as 'shopping', 'public transportation service', 'unique architecture', appeal of the tourist site', 'accommodation', and 'food', also appear to be relevant to average tourist satisfaction. All the relevant satisfaction factors are positively related, and this can be predicted by common sense. Since 'security' and 'tourist information service' have high significance levels, it is difficult to state their relevance. None of the variables in tourist characteristics shows low significance levels to confirm the relevance.

Among all the factors of tourism, 'beautiful cityscape' has the highest ' $\beta$ ' value followed by 'lively streets'. Therefore, it can be concluded that urban factors, as in 'beautiful cityscape' and 'lively streets', have a crucial effect on tourist satisfaction.

\section{Conclusion}

Tourists visiting Seoul had high expectations of the 'appeal of the tourist site', 'food', and 'accommodation'. The actual experience of 'food' was much better than what they expected while the experience of the 'appeal of the tourist site' was just above expectations (Table 2). The average points for experience were high when it came to 'food', 'public transportation service', and 'security'. The expectation of 'beautiful cityscape' was very low, while the expectation for 'lively streets' was around the mid-level. The actual experience of the cityscape was relatively low, but because the expectation was so low, the difference between the experience and the expectation, which in this article was measured as satisfaction, was relatively high. Other factors that had high satisfaction levels were 'security' and 'public transportation service'. The satisfaction level for 'lively streets' was relatively high. By measuring the expectations for each tourism factor, we were able to identify what the tourists expected when they travelled to Seoul.

The results of the ordered logistic regression (Table 3 ) show that the urban factors of 'beautiful cityscape' and 'lively streets' had high $\beta$ values which indicated that these factors had a greater influence on tourist satisfaction than the other measured factors. From the results in Tables 2 and 3, it can be concluded that urban factors are very important in tourist satisfaction, but most tourists visiting Seoul do not expect the cityscape of Seoul to be beautiful. Therefore, to increase the number of tourists and to maintain a high level of tourist satisfaction, urban factors, especially cityscape, should be improved.

The diversity in the built environment of each city is what triggers tourism. Unique architecture, historic sites and buildings, parks, shopping districts, and cultural impressions combined in streets and buildings bring tourists to major cities (Ashworth and Tunbridge 1990; Law 1993). However, this uniqueness, which is the purpose of tourism, is under constant threat. The spread of modern construction and the growth of globalisation have tended to result in homogeneity across cities (Edwards et al. 2008). The tourist industry accelerates this homogeneity. When a place attracts tourists for its unique sense of place, the rent and land prices tend to increase, causing local shops that contributed to that very uniqueness to be replaced by global franchises. This phenomenon is also very common in Seoul. More than six centuries of accumulated history is being replaced by contemporary buildings. Since the number of tourists visiting Seoul has increased rapidly over the last decade, the rate of such replacements is accelerating. However, the government still focuses on building more duty-free shops and hotels rather than preserving and improving the cityscape.

By showing that tourist satisfaction is influenced more by the beautiful cityscape and liveliness than by shopping or accommodation options, this article emphasises the significance of the built environment in city tourism through scholarly investigation. The priority in tourism policies should be the preservation of the urban environment and the reinforcement of the identity of the city. Some would consider the findings of this study as a means of enhancing tourism by analysing the elements that affect the satisfaction of tourists, and by building an environment that can enhance tourist satisfaction. However, this study is not about creating a new place for tourists, but rather about enhancing the identity of a place through urban planning and urban design tools.

Acknowledgements This research was supported by the CreativePioneering Researchers Program, the Integrated Research Institute of Construction and Environmental Engineering, and the Institute of Engineering Research at Seoul National University (SNU). This research was partially supported by the Basic Science Research Program through the National Research Foundation of Korea, funded by the Ministry of Education (2018R1D1A1B07048832). This research was conducted by supplementing part of the doctoral thesis of the first author, Chehyun Ryu.

Author contributions CR and YK conceived and designed the experiments; CR conducted in-depth interviews; CR prepared the transcripts and analysed the data; CR and YK wrote the paper. 


\section{Declarations}

Conflict of interest There are no conflicts of interest to declare. The sponsors had no role in study design; collection, analyses, or interpretation of data; writing of the manuscript; or decision to publish the results.

Open Access This article is licensed under a Creative Commons Attribution 4.0 International License, which permits use, sharing, adaptation, distribution and reproduction in any medium or format, as long as you give appropriate credit to the original author(s) and the source, provide a link to the Creative Commons licence, and indicate if changes were made. The images or other third party material in this article are included in the article's Creative Commons licence, unless indicated otherwise in a credit line to the material. If material is not included in the article's Creative Commons licence and your intended use is not permitted by statutory regulation or exceeds the permitted use, you will need to obtain permission directly from the copyright holder. To view a copy of this licence, visit http://creativecommons.org/licenses/by/4.0/.

\section{References}

Agyeiwaah, E., F.E. Otoo, W. Suntikul, and W.J. Huang. 2019. Understanding Culinary Tourist Motivation, Experience, Satisfaction, and Loyalty Using a Structural Approach. Journal of Travel \& Tourism Marketing 36 (3): 295-313.

Ahn, N.Y. 2011. A Study on Formation Factors of the Sense of Place in Three Town Centers of Bundang New Town. Ph.D diss.: Seoul National University.

Alegre, J., and J. Garau. 2010. Tourist Satisfaction and Dissatisfaction. Annals of Tourism Research 37: 52-73.

Ashworth, G.J., and J.E. Tunbridge. 1990. The Tourist-Historic City. London: Belhaven Press.

Barker, M. 2002. Visitor Safety in Urban Tourism Environments: The Case of Auckland, New Zealand. Cities 19 (4): 273-282.

Bradley, A., Y. Hall, and M. Harrison. 2002. Selling Cities, Promoting New Images for Meetings Tourism. Cities 19 (1): 61-70.

Brown, G., and C. Raymond. 2007. The Relationship Between Place Attachment and Landscape Values: Toward Mapping Place Attachment. Applied Geography 27 (2): 89-111.

Burgess, J.A. 1982. Selling Places: Environmental Images for the Executive. Regional Studies 16: 1-17.

Chen, C.C., W.J.J. Huang, and J.F. Petrick. 2015. Holiday Recovery Experiences, Tourism Satisfaction and Life Satisfaction - Is There a Relationship? Tourism Management 53: 140-147.

Christaller, W. 1963. Some Considerations of Tourism Location in Europe: The Peripheral Regions -Underdeveloped CountriesRecreation Areas. Regional Science Association 12: 95-105.

Chu, R.K.S., and T. Choi. 2000. An Importance-Performance Analysis of Hotel Selection Factors in the Hong Kong Hotel Industry: A Comparison of Business and Leisure Travellers. Tourism Management 21 (4): 363-377.

Churchill, G.A., and C. Surprenant. 1982. An Investigation into the Determinants of Customer Satisfaction Decisions. Journal of Marketing Research 19 (4): 491-504.

Cohen, E. 1979. A Phenomenology of Tourist Experiences. Sociology 13 (2): 179-201.

Crompton, J. 1979. Motivations for Pleasure Vacation. Annals of Tourism Research 6 (4): 408-424.

Cronin, J.J., and S.T. Taylor. 1994. SERVPERF versus SERVQUAL: Reconciling Performance-Based and Perceptions-Minus-Expectations Measurement of Service Quality. Journal of Marketing 58: $125-131$.
Crossley, J., and Z.B. Xu. 1996. Three Satisfaction Models Compared in Survey of Taiwanese Tourists. Visions in Leisure and Business 15 (2): 4-14.

Della Corte, V., and R. Micera. 2011. Resource Integration Management in Networks' Value Creation: The Case of High Quality Hotel. Mercati e Competitivita 3: 127.

Edwards, D., T. Griffin, and B. Hayllar. 2008. Urban Tourism Research Developing an Agenda. Annals of Tourism Research 35 (4): 1032-1052.

Eizenberg, E., and N. Cohen. 2015. Reconstructing Urban Image Through Cultural Flagship Events: The Case of Bat-Yam. Cities 42: 54-62.

Fernández-Herrero, M., R.M. Hernández-Maestro, and Ó. GonzálezBenito. 2018. Autonomy in Trip Planning and Overall Satisfaction. Journal of Travel \& Tourism Marketing 35 (2): 119-129.

Fick, G.R., and J.R.B. Ritchie. 1991. Measuring Service Quality in the Service Industry. Journal of Travel Research 30 (2): 2-9.

Foster, D. (1999) Measuring Customer Satisfaction in the Tourism Industry. Paper presented at the Third International and Sixth National Research Conference on Quality Management, Melbourne, Australia, February 8-10.

Gospodini, A. 2001. Urban Design, Urban Space Morphology, Urban Tourism: An Emerging New Paradigm Concerning Their Relationship. European Planning Studies 9 (7): 925-934.

Haywood, K.M., and T.E. Muller. 1988. The Urban Tourist Experience: Evaluating Satisfaction. Hospitality Education and Research Journal 12 (2): 453-459.

Hinch, T.D. 1996. Urban Tourism: Perspectives on Sustainability. Journal of Sustainable Tourism 4 (2): 95-110.

Iso-Ahola, S.E. 1982. Toward a Social Psychological Theory of Tourism Motivation: A Rejoinder. Annals of Tourism Research 9 (2): 256-262.

Johnson, M.D., E.W. Anderson, and C. Fornell. 1995. Rational and Adaptive Performance Expectations in a Customer Satisfaction Framework. Journal of Consumer Research 21 (4): 695-707.

Judd, D.R., and M. Collins. 1979. The Case of Tourism: Political Coalitions and Redevelopment in Central Cities. In The Changing Structure of Cities: What Happened to the Urban Crisis?, ed. G. Tobin, 177-199. SAGE: Beverly Hills, CA.

Karski, A. 1990. Urban Tourism: A Key to Urban Regeneration? Plan 76: $13-17$

Kyle, G.T., A.R. Graefe, R. Manning, and J. Bacon. 2004. Effects of Place Attachment on Users' Perceptions of Social and Environmental Conditions in a Natural Setting. Journal of Environmental Psychology 24 (2): 213-225.

Law, C.M. 1993. Urban Tourism: Attracting Visitors to Large Cities. London: Mansell Publishing.

Liu, C.H.S. 2015. The Relationships Among Brand Equity, Culinary Attraction, and Foreign Tourist Satisfaction. Journal of Travel \& Tourism Marketing 33 (8): 1143-1161.

Lynch, K. 1960. The Image of the City. Cambridge, MA: The MIT Press.

Mannell, R.C., and S.E. Iso-Ahola. 1987. Psychological Nature of Leisure and Tourism Experience. Annals of Tourism Research 14 (3): 314-331.

McKelvey, R.D., and W. Zavoina. 1975. A Statistical Model for the Analysis of Ordinal Level Dependent Variables. The Journal of Mathematical Sociology 4: 103-120.

Oh, H. 2001. Revisiting Importance-Performance Analysis. Tourism Management 22 (6): 617-627.

Oliver, R.L. 1980. A Cognitive Model of the Antecedents and Consequences of Satisfaction Decisions. Journal of Marketing Research 17 (4): 460-469.

Oliver, R.L., R.T. Rust, and S. Varki. 1997. Customer Delight: Foundations, Findings, and Managerial Insight. Journal of Retailing 73 (3): 311-336. 
Owen, C. 1990. Tourism and Urban Regeneration. Cities 7 (3): 194-201.

Page, S.J. 1993. Urban Tourism in New Zealand: The National Museum of New Zealand Project. Tourism Management 14 (3): 211-228.

Parahoo, S.K., H.L. Harvey, and G.Y.A. Radi. 2014. Satisfaction of Tourists with Public Transport: An Empirical Investigation in Dubai. Journal of Travel \& Tourism Marketing 31 (8): 1004-1017.

Parasuraman, A., V.A. Zeithaml, and L.L. Berry. 1988. SERVQUAL: A Multiple-Item Scale for Measuring Consumer Perceptions of Service Quality. Journal of Retailing 64: 12-40.

Parasuraman, A., V.A. Zeithaml, and L.L. Berry. 1994. Reassessment of Expectations as a Comparison Standard in Measuring Service Quality: Implications for Further Research. Journal of Marketing 58: 111-124.

Parasuraman, A., V.A. Zeithaml, and L.L. Berry. 1998. A Conceptual Model of Service Quality and Its Implications for Future Research. Journal of Marketing 49 (4): 41-50.

Pearce, P.L. 1977. Mental Souvenirs: A Study of Tourists and Their City Maps. Australian Journal of Psychology 29 (3): 203-210.

Prayag, G., and C. Ryan. 2011. The Relationship Between the "Push" and "Pull" Factors of a Tourist Destination: The Role of Nationality-An Analytical Qualitative Research Approach. Current Issues in Tourism 14 (2): 121-143.

Ryan, C., and J. Huyton. 2002. Tourists and Aboriginal People. Annals of Tourism Research 29 (3): 631-647.

Saleh, F., and C. Ryan. 1992. Conviviality-A Source of Satisfaction for Hotel Guests? An Application of the SERVQUAL Model, Choice and Demand in Tourism. In Choice and Demand in Tourism, ed. P. Johnson and B. Thomas, 107-122. London: Mansell Publishing.

Schewe, C.D., D.R. Scott, and D.G. Frederick. 1978. A Multi-Brand/ Multi-Attribute Model of Tourism State Choices. Journal of Travel Research 17: 23-29.
Selby, M. 2004. Consuming the City: Conceptualizing and Researching Urban Tourist Knowledge. Tourism Geographies 6 (2): 186-207.

Stansfield, C.A. 1964. A Note on the Urban-Nonurban Imbalance in American Recreational Research. The Tourist Review 19 (4): 196-200.

Tribe, J., and T. Snaith. 1998. From SERVQUAL to HOLAST: Holiday Satisfaction in Varadero, Cuba. Tourism Management 19: 25-34.

Turner, V. 1973. The Center Out There: Pilgrim's Goal. History of Religions 12 (3): 191-230.

Wang, C., and M.K. Hsu. 2010. The Relationships of Destination Image, Satisfaction, and Behavioral Intentions: An Integrated Model. Journal of Travel \& Tourism Marketing 27 (8): 829-843.

Wang, Y. (2016) More Important Than Ever: Measuring Tourist Satisfaction. Griffith Institute for Tourism Research Report Series, Report No. 10, Griffith University: Queensland, Australia.

Wang, Y., and M.C.G. Davidson. 2010. Chinese Holiday Makers' Expenditure: Implications for Marketing and Management. Journal of Hospitality Marketing \& Management 19 (4): 373-396.

Wang, Y., K.K.F. So, and B.A. Sparks. 2016. Technology Readiness and Customer Satisfaction with Travel Technologies: A Cross-Country Investigation. Journal of Travel Research 56 (5): 563-577.

Wearing, S.L., and C. Foley. 2017. Understanding the Tourist Experience of Cities. Annals of Tourism Research 65: 97-107.

Yu, L., and M. Goulden. 2006. A Comparative Analysis of International Tourists' Satisfaction in Mongolia. Tourism Management 27 (6): 1331-1342.

Publisher's Note Springer Nature remains neutral with regard to jurisdictional claims in published maps and institutional affiliations. 